\title{
Implikasi hukum teknologi informasi dalam perkembangan teknologi pendidikan islam (Telaah atas Hukum Moore, Hukum Metcalfe, dan Hukum Coase)
}

\author{
Husna Nashihin a,1, ${ }^{*}$, Anisatul Baroroh b,2, Aslam Ali c,3 \\ a Universitas Wahid Hasyim, Semarang, Jawa Tengah, Indonesia; \\ b Sekolah Tinggi Agama Islam NU Temanggung, Jawa Tengah, Indonesia; \\ c Sekolah Tinggi Ilmu Tarbiyah Madani Yogyakarta, Yogyakarta, Indonesia; \\ *1 aufahusna.lecture2017@gmail.com; ${ }^{2}$ aninisbaba@gmail.com; ${ }^{3}$ aliassalam@gmail.com \\ *Correspondent Author
}

\section{KATAKUNCI}

Implikasi Hukum Teknologi

Pendidikan Islam

\section{KEYWORDS}

Implications of Law Technology Islamic Education

\section{ABSTRAK}

Paradigma lama mengenai metode belajar mengajar pada era digital sudah berubah menjadi paradigma baru berbasis teknologi online. Bahkan, teknologi ini dalam dunia Pendidikan sudah merubah dunia Pendidikan menjadi wajah baru yang mampu menembus batas ruang dan waktu. Penelitian ini digolongkan ke dalam jenis penelitian literer, yaitu dalam proses perolehan data sesuai dengan sasaran atau masalah penelitian yang diperlukan sebuah informasi yang selengkap- lengkapnya atau sedalam-dalamnya mengenai gejalagejala yang ada dalam lingkup obyek penelitian. Pemanfaatan Teknologi Informasi, media, dan komunikasi telah mengubah baik perilaku masyarakat maupun peradaban manusia secara global. Perkembangan teknologi informasi dan komunikasi telah pula menyebabkan hubungan dunia menjadi tanpa batas (borderless) dan menyebabkan perubahan sosial, ekonomi, dan budaya secara signifikan berlangsung demikian cepat. Teknologi informasi ibarat mata uang koin, mempunyai dua mata sisi, yaitu ; sisi negatif dan sisi positif, sehingga guru di dalam menyampaikan materi tidak menjadikan teknologi informasi sebagai sumber melainkan sebagai media dalam pembelajaran.

The legal implications of information technology in the development of Islamic education technology (A study of Moore's Law, Metcalfe's Law, and Coase's Law)

The old paradigm regarding teaching and learning methods in the digital era has turned into a new paradigm based on online technology. In fact, this technology in the world of education has changed the world of education into a new face that is able to penetrate the boundaries of time and space. This research is classified into the type of literary research, namely in the process of obtaining data in accordance with the objectives or research problems required a complete or profound information regarding the symptoms that are within the scope of the research object. The use of information technology, media and communication has changed both the behavior of society and human civilization globally. The development of information and communication technology has also caused world relations to become borderless and caused significant social, economic and cultural changes to take place so rapidly. Information 
technology is like a coin, has two sides, namely; the negative side and the positive side, so that the teacher in delivering the material does not use information technology as a source but as a medium in learning.

This is an open-access article under the CC-BY-SA license.

\section{Pendahuluan}

Perkembangan teknologi informasi dan komunikasi (TIK) telah memberikan pengaruh terhadap dunia pendidikan khususnya dalam proses pembelajaran. Menurut Rosenberg (2001), dengan berkembangnya penggunaan TIK ada lima pergeseran dalam proses pembelajaran yaitu:(1) dari pelatihan ke penampilan, (2) dari ruang kelas ke di mana dan kapan saja, (3) dari kertas ke "on line" atau saluran, (4) fasilitas fisik ke fasilitas jaringan kerja, (5) dari waktu siklus ke waktu nyata. Komunikasi sebagai media pendidikan dilakukan dengan menggunakan media-media komunikasi seperti telepon, komputer, internet, e-mail, dsb. Interaksi antara guru dan siswa tidak hanya dilakukan melalui hubungan tatap muka tetapi juga dilakukan dengan menggunakan media-media tersebut. Guru dapat memberikan layanan tanpa harus berhadapan langsung dengan siswa. Demikian pula siswa dapat memperoleh informasi dalam lingkup yang luas dari berbagai sumber melalui cyber space atau ruang maya dengan menggunakan komputer atau internet.

Dalam dunia pendidikan teknologi pendidikan lebih banyak dikenal dengan cybereducation. Cyber berasal dari bahasa Yunani, kubernan yang berarti memandu, mengarahkan, menguasai. Norbert Wiener, pada tahun 1948 menemukan istilah cybernetics untuk menggambarkan sistem pengontrolan yang menggunakan komputer. Sejak itu penggunaan awal cyber pun banyak bermunculan seperti cyberspace(1984), cyberia, cybersex, cyberotics, dan cyberpunk. Dalam perkembangannya cyber lebih akrab dalam dunia teknologi sehingga berbagai bidang lain yang berkait dengan teknologi seringkali disandingkan dengan istilah cyber.

Seiring perkembangan berbagai bidang yang ada dalam kehidupan, pembelajaran juga ikut mengalami perkembangan yang cukup signifikan, yang disebut sebagai revolusi pembelajaran. Berbagai terobosan dalam pembelajaran telah ditemukan. Sebagian berasal dari guru-guru yang kompeten, sebagian dari dunia bisnis, sebagian dari psikologi, olah raga dan teknik-teknik kepelatihan. Istilah cybereducation pun muncul, sebagai salah satu bentuk pendidikan yang memanfaatkan peran teknologi. "ini hal yang baru yang menyenangkan dalam lahan pendidikan, terutama bagi pengajar, administrator, web designer, pengembang sistem dan semua pihak yang antusias pada pengembangan internet untuk pegajaran.

Gordon Dryden dan Jeannette Vos dalam bukunya The Learning Revolution menyatakan bahwa kita hidup di era pertama sepanjang sejarah manusia ketika setiap orang dapat berkomunikasi dengan siapa saja dan merupakan era pertama ketika anak-anak lebih menguasai teknologi dominan dibandingkan para guru dan orang tua. Menurutnya pula, revolusi gabungan internet-komputer-Word Wide Web ini membentuk generasi baru yang lebih dahsyat dibandingkan revolusi yang dipicu oleh temuan percetakan, radio, mobil dan televisi.

Hal yang penting, revolusi digital memicu munculnya pemikiran ulang tentang metode belajar dan mengajar. Di bidang sains saja, sekitar 10.000 artikel baru dipublikasikan setiap hari. Tidak ada guru sains yang mampu membaca sebagian kecil saja apalagi semua materi tersebut. Paradigma lama mengenai metode belajar mengajar pada era digital sudah berubah menjadi paradigma baru berbasis teknologi online. Bahkan, teknologi ini dalam dunia Pendidikan sudah merubah dunia Pendidikan menjadi wajah baru yang mampu menembus 
batas ruang dan waktu.

Dalam perkembangannya, teknologi informasi dan informasi menghasilkan sebuah hukum yang didalamnya mencakup beberapa aspek. Dari beberapa aspek tersebut, maka secara nyata akan berimplikasi pada semua hal, baik dalam bidang perekonomian, pendidikan dan hal lainnya. Seiring berkembangnya teknologi dan informasi maka muncul pula hukum-hukum yang berkaitan dengan dengan teknologi. Disini yang dimaksud hukum teknologi dan informasi bukan berkaitan dengan masalah kriminalitas pidana maupun perdata, akan tetapi berkaitan dengan masalah perkembangan dan teori berkaitan dengan teknologi. Dari faktor inilah peneliti mencoba untu menggali bagaimanakah hukum-hukum teknologi dan implikasinya terhadap pembelajaran.

\section{Metode}

Penelitian ini digolongkan ke dalam jenis penelitian literer, yaitu dalam proses perolehan data sesuai dengan sasaran atau masalah penelitian yang diperlukan sebuah informasi yang selengkap- lengkapnya atau sedalam-dalamnya mengenai gejala-gejala yang ada dalam lingkup obyek penelitian. Dari gejala-gejala penelitian yang ada dalam penelitian ini bukanlah satu-satunya yang berdiri, melainkan saling berkaitan antara satu sama lain dalam kesatuan yang menyeluruh yang biasanya dikenal dengan pendekatan. Dalam penelitian ini, pengumpulan data menggunakan tiga metode utama yaitu : wawancara, observasi dan dokumentasi.

\section{Hasil dan Pembahasan}

\section{Definisi Teknologi Informasi}

Hasil dan Pembahasan dapat disajikan dalam subbab. Membahas secara jelas pokok bahasan sesuai dengan masalah, tujuan penelitian, dan teori yang digunakan.

Pengertian Teknologi sebenarnya berasal dari kata Bahasa Perancis yaitu "La Teknique" yang dapat diartikan dengan "Semua proses yang dilaksanakan dalam upaya untuk mewujudkan sesuatu secara rasional". Dalam hal ini yang dimaksudkan dengan sesuatu tersebut dapat saja berupa benda atau konsep, pembatasan cara yaitu secara rasional adalah penting sekali dipahami disini sedemikian pembuatan atau pewujudan sesuatu tersebut dapat dilaksanakan secara berulang (repetisi).

Teknologi dalam arti ini dapat diketahui melalui barang-barang, benda-benda, atau alatalat yang berhasil dibuat oleh manusia untuk memudahkan dan menggampangkan realisasi hidupnya di dalam dunia. Hal mana juga memperlihatkan tentang wujud dari karya cipta dan karya seni (Yunani techne) manusia selaku homo technicus. Dari sini muncullah istilah "teknologi", yang berarti ilmu yang mempelajari tentang "techne" manusia. Tetapi pemahaman seperti itu baru memperlihatkan satu segi saja dari kandungan kata "teknologi". Teknologi sebenarnya lebih dari sekedar penciptaan barang, benda atau alat dari manusia selaku homo technicus atau homo faber. Teknologi bahkan telah menjadi suatu sistem atau struktur dalam eksistensi manusia di dalam dunia. Teknologi bukan lagi sekedar sebagai suatu hasil dari daya cipta yang ada dalam kemampuan dan keunggulan manusia, tetapi ia bahkan telah menjadi suatu "daya pencipta" yang berdiri di luar kemampuan manusia, yang pada gilirannya kemudian membentuk dan menciptakan suatu komunitas manusia yang lain.

Pemanfaatan Teknologi Informasi, media, dan komunikasi telah mengubah baik perilaku masyarakat maupun peradaban manusia secara global. Perkembangan teknologi informasi dan komunikasi telah pula menyebabkan hubungan dunia menjadi tanpa batas (borderless) dan menyebabkan perubahan sosial, ekonomi, dan budaya secara signifikan berlangsung demikian cepat. Teknologi Informasi saat ini menjadi pedang bermata dua karena selain memberikan kontribusi bagi peningkatan kesejahteraan, kemajuan, dan peradaban manusia, 
sekaligus menjadi sarana efektif perbuatan melawan hukum.

Yang dimaksud dengan sistem elektronik adalah sistem komputer dalam arti luas, yang tidak hanya mencakup perangkat keras dan perangkat lunak komputer, tetapi juga mencakup jaringan telekomunikasi dan/atau sistem komunikasi elektronik. Perangkat lunak atau program komputer adalah sekumpulan instruksi yang diwujudkan dalam bentuk bahasa, kode, skema, ataupun bentuk lain, yang apabila digabungkan dengan media yang dapat dibaca dengan komputer akan mampu membuat komputer bekerja untuk melakukan fungsi khusus atau untuk mencapai hasil yang khusus, termasuk persiapan dalam merancang instruksi tersebut.

Sistem elektronik juga digunakan untuk menjelaskan keberadaan sistem informasi yang merupakan penerapan teknologi informasi yang berbasis jaringan telekomunikasi dan media elektronik, yang berfungsi merancang, memproses, menganalisis, menampilkan, dan mengirimkan atau menyebarkan informasi elektronik. Sistem informasi secara teknis dan manajemen sebenarnya adalah perwujudan penerapan produk teknologi informasi ke dalam suatu bentuk organisasi dan manajemen sesuai dengan karakteristik kebutuhan pada organisasi tersebut dan sesuai dengan tujuan peruntukannya. Pada sisi yang lain, sistem informasi secara teknis dan fungsional adalah keterpaduan sistem antara manusia dan mesin yang mencakup komponen perangkat keras, perangkat lunak, prosedur, sumber daya manusia, dan substansi informasi yang dalam pemanfaatan fungsi input, process, output, storage, dan communication.

Kegiatan melalui media sistem elektronik, yang disebut juga ruang siber (cyber space), meskipun bersifat virtual dapat dikategorikan sebagai tindakan atau perbuatan hukum yang nyata. Secara yuridis kegiatan pada ruang siber tidak dapat didekati dengan ukuran dan kualifikasi hukum konvensional saja sebab jika cara ini yang ditempuh akan terlalu banyak kesulitan dan hal yang lolos dari pemberlakuan hukum. Kegiatan dalam ruang siber adalah kegiatan virtual yang berdampak sangat nyata meskipun alat buktinya bersifat elektronik.

Dengan demikian, subjek pelakunya harus dikualifikasikan pula sebagai Orang yang telah melakukan perbuatan hukum secara nyata. Dalam kegiatan ecommerce antara lain dikenal adanya dokumen elektronik yang kedudukannya disetarakan dengan dokumen yang dibuat di atas kertas.

\section{Hukum Teknologi Informasi}

Marshall McLuhan adalah pencetus dari teori determinisme teknologi ini pada tahun 1962 melalui tulisannya The Guttenberg Galaxy : The Making of Typographic Man. Dasar teorinya adalah perubahan pada cara berkomunikasi akan membentuk cara berpikir, berperilaku, dan bergerak ke abad teknologi selanjutnya di dalam kehidupan manusia.

Sebagai intinya adalah determinisme teori, yaitu penemuan atau perkembangan teknologi komunikasi merupakan faktor yang mengubah kebudayaan manusia. Seperti yang disampaikan dalam edisi kelima buku A First Look at Communication Theory by Griffin dan Emory A, McLuhan memetakan sejarah peradaban kehidupan manusia ke dalam empat periode:

a. The Tribal Age. Menurut McLuhan, pada era ini dikenal dengan nama era purba atau era suku zaman dahulu, manusia hanya mengandalkan indera pendengaran dalam berkomunikasi. Komunikasi pada era ini hanya mendasarkan diri pada narasi, cerita, dongeng tuturan, dan sejenisnya dimana telinga adalah "raja", atau dalam istilah lama orang mengenal paham"hearing is believing", dan kemampuan visual manusia belum banyak diandalkan dalam komunikasi. sehingga, Era primitif ini kemudian tergusur dengan ditemukannya alfabet atau huruf.

b. The Age of Literacy. Semenjak ditemukannya alfabet atau huruf, maka cara manusia berkomunikasi banyak berubah. Indera penglihatan kemudian menjadi dominan di era ini, 
mengalahkan indera pendengaran. Manusia berkomunikasi tidak lagi mengandalkan tuturan, tapi lebih kepada tulisan.

c. The Print Age. Era ini dimulai sejak ditemukannya mesin cetak yang menjadikan alfabet semakin menyebarluas ke penjuru dunia. Kekuatan kata-kata melalui mesin cetak tersebut semakin merajalela. Kehadiran mesin cetak, dan kemudian media cetak, menjadikan manusia lebih bebas lagi untuk berkomunikasi.

d. The Electronic Age. Era ini juga menandai ditemukannya berbagai macam alat atau teknologi komunikasi. Telegram, telpon, radio, film, televisi, VCR, fax, komputer, dan internet. Manusia kemudian menjadi hidup di dalam apa yang disebut sebagai "global village". Media massa pada era ini mampu membawa manusia mampu untuk bersentuhan dengan manusia yang lainnya, kapan saja, di mana saja, dan seketika itu juga.

McLuhan juga menyebutkan bahwa media massa adalah ekstensi atau perpanjangan dari inderawi manusia (extention of man). Media tidak hanya memperpanjang jangkauan kita terhadap suatu tempat, peristiwa, informasi, tapi juga menjadikan hidup kita lebih efisien. Lebih dari itu media juga membantu kita dalam menafsirkan tentang kehidupan kita.

Dalam perspektif McLuhan, media itu sendiri lebih penting daripada isi pesan yang disampaikan oleh media tersebut. Misalkan saja, mungkin isi tayangan di televisi memang penting atau menarik, akan tetapi sebenarnya kehadiran televisi di ruang keluarga tersebut menjadi jauh lebih penting lagi. Televisi, dengan kehadirannya saja sudah menjadi penting, bukan lagi tentang isi pesannnya. Kehadiran media massa telah lebih banyak mengubah kehidupan manusia, lebih dari apa isi pesan yang mereka sampaikan.

Inti dari teori McLuhan ini jelas menjadi gambaran yang disebut determinisme teklologi. Yang berarti penemuan atau perkembangan teknologi komunikasi yang sebenarnya yang mengubah kebudayaan manusia.Determinisme menurut sumber wikipedia indonesia berasal dari bahasa Latin determinare yang artinya menentukan atau menetapkan batas atau membatasi. Secara umum, pemikiran ini berpendapat bahwa keadaan hidup dan perilaku manusia ditentukan oleh faktor-faktor fisik geografis, biologis, psikologis,sosiologis, ekonomis dan keagamaan yang ada termasuk didalamnya perubahan pada peradaban manusia. Determinisme juga berpegangan bahwa perilaku etis manusia ditentukan oleh lingkungan, adat istiadat, tradisi, norma dan nilai etis masyarakat. Istilah ini dimasukkan menjadi istilah filsafat oleh William Hamilton yang menerapkannya pada Thomas Hobbes. Penganut awal pemikiran determinisme ini adalah demokritos yang percaya bahwa sebabakibat menjadi penjelasan bagi semua kejadian sesuai dengan landasan setiap perubahan yang terjadi didalamnya. Jadi, dapat disimpulkan bahwa menurut McLuhan eksistensi manusia ditentukan oleh perubahan mode komunikasi dimasing-masing tempat berlangsungnya peradaban mereka.

Namun tidak sebatas ini saja, ternyata hadirnya sekian banyak teknologi disekian peradaban yang dilalui manusia ternyata masih saja ditemui dilema yang kemudian muncul seiring dengan semakin pesatnya perkembangan teknologi komunikasi yaitu berupa keadaan dimana manusia semakin didominasi oleh teknologi komunikasi yang diciptakannya sendiri. Teknologi komunikasi bukannya dikontrol oleh manusia namun justru kebalikannya, kita yang dikontrol oleh mereka. Sebagai contoh, betapa gelisahnya kita kalau sampai terlewat satu episode sinetron kesayangan yang biasanya kita tonton tiap hari. Atau mungkin kalau kita sudah lebih dari seminggu tidak membuka halaman Friendster di internet. Satu hari saja tidak menonton televisi mungkin kita akan merasa betapa kita telah ketinggalan berapa banyak informasi hari itu. Ini menjadi fakta bahwa kehadiran media massa, dan segala kemajuan teknologi komunikasi lainnya yang seharusnya menjadikan kehidupan manusia lebih baik justru menjadi sebuah ironi dimana dominasi media massa dan teknologi komunikasi semakin pesat dan tidak begitu membaik.

Sains dan teknologi adalah sebuah bentuk 'pembentangan kemungkinan dunia' (possible world) atau sebuah 'perluasan medan pengalaman' (field of experience). Melalui sains dan 
teknologi 'dibentangkan' sebuah dunia yang belum pernah ada, belum terbayangkan atau belum terimajinasikan sebelumnya. Akan tetapi, pembentangan sains dan teknologi adalah pembentangan penuh ambiguitas. Di satu pihak, sains dan teknologi membentangkan semacam horizon pengharapan (horizon of expectation): pengembaraan tak bertepi, pengetahuan tanpa batas, pengalaman tanpa pembatas. Di pihak lain, ia menciptakan pula 'ketakterlukisan yang enigmatik', 'kecemasan yang tanpa akhir' (anxiety), 'rasa ketakamanan ontologis' (ontological insecurity), 'keterserapan dan kecanduan', serta 'ketakpastian identitas dan subyektivitas'.

Penemuan atau perkembangan teknologi komunikasi merupakan faktor yang mengubah kebudayaan manusia. Dalam pendidikan agama Islam perubahan kebudayaan sangat berpengaruh sehingga kebudayaan antara satu negara dengan negara lainnya lebih mudah dikenal. Semua orang mempunyai peluang untuk mengikuti dan mengidentifikasi perbuatan yang akan diikuti baik positif maupun negatif. Teori ini menggambarkan bahwa determinasi sebagai faktor pengubah kebudayaaan akan berimplikasi pada cara pandang pendidikan agama Islam di dalam memfilter dan mengantisipasi kebudayaan yang sikapnya negatif dan tidak baik. begitu pula sebaliknya, kebudayaan yang baik diambil dan dijadikan sebagai acuan.

Ada tiga kecenderungan utama pemikiran tentang sains dan teknologi dalam perannya membangun sebuah 'rumah' (oikos) atau 'tempat' (topos) bagi masyarakat manusia, yaitu: 1) utopianisme (utopianism) sebagai pandangan optimis tentang peran positif sains dan teknologi, 2) distopianisme (dystopianism), sebagai pandangan pesimis tentang sains dan teknologi, dan 3) 'hiper-topianisme' (hypertopianism), sebagai pandangan 'fatalis' tentang sains dan teknologi.

Utopianisme, sebagai sebuah kecenderungan pemikiran tentang sebuah 'masyarakat tanpa cela' (perfect society) di masa depan dan peran sentral sains dan teknologi dalam membangunnya. 'Utopia' dalam bahasa Yunani berarti 'takbertempat'. Thomas More menggunakan istilah 'utopia' untuk menggambarkan sebuah masyarakat imajiner yang berada di sebuah tempat yang jauh, sebagai model kehidupan masyarakat masa depan yang demokratis dan tanpa kelas, dengan orangorang yang bijak. 'Utopia' menjadi sebuah istilah generik untuk melukiskan segala bentuk cerita atau narasi yang menceritakan sebuah komunitas di masa depan di mana segala sesuatu berlangsung indah, menyenangkan dan tanpa cela. Marshal McLuhan, misalnya, secara optimis melihat teknologi sebagai sebuah utopia 'perpanjangan manusia' di masa depan. Pandangan optimistik semacam ini diperlihatkan pula oleh berbagai pemikir, seperti Francis Bacon, New Atlantis (1624),

Herman Kahn, The Next 200 Years (1976) sampai Howard Rheingold, Virtual Reality (1993).

Utopianisme membahas bentuk 'pembentangan kemungkinan dunia' (possible world) atau sebuah 'perluasan medan pengalaman' (field of experience). Melalui sains dan teknologi 'dibentangkan' sebuah dunia yang belum pernah ada, belum terbayangkan atau belum terimajinasikan sebelumnya. Secara nyata dengan adanya teknologi informasi akan berimplikasi baik di dalam meluasnya pengalaman guru dan peserta didik. Setiap individu dapat dengan mudah mengakses informasi secara luas, mendetail dan mendalam. Tetapi disi lain informasi yang negatif pun dengan sangat mudah menjalur pada setiap informasi. Berkaitan dengan pembelajaran PAI agaknya teori teknologi ini juga sangat berimplikasi. Hal yang pertama yang sangat urgen adalah pengalaman akan meluas. Akan tetapi disisi lain terkadang semakin meluasnya teknologi menimbulkan permasalahan yang baru, yaitu munculnya permasalahan-permasalahan yang membutuhkan kajian lebih mendalam di dalam menggambil keputusan hukum. 


\section{Implikasi Hukum Moore dalam Perkembangan Teknologi Pendidikan Islam}

Gordon Moore mengungkapkan teori perkembangan teknologi informasi sebagai berikut; "Kekuatan mikroprosesor menjadi dua kali lipat setiap 18 bulan. Kekuatan komputasi menjadi dua kali lipat setiap 18 bulan. Harga komputasi berkurang setengahnya setiap 18 bulan." (Gordon Moore, 1965)

Gordon Earle Moore dilahirkan pada tanggal 3 Januari 1929 di San Francisco, California, Amerika Serikat. Ia merupakan salah satu pendiri dan Chairman Emeritus dari Intel Corporation dan pencetus hukum Moore yakni salah satu hukum yang terkenal dalam industri mikroprosesor yang menjelaskan tingkat pertumbuhan kecepatan mikroprosesor. ia dan keluarganya tinggal di Pescadero yang berlokasi tidak jauh dari San Fransisco dimana ia dibesarkan. Dia pergi meninggalkan kampung halamannya untuk menuntut pendidikan yang diselesaikannya Ia mendapatkan gelar B.S. untuk Kimia dari University of California, Berkeley pada 1950, pada tahun 1954 dengan gelar Ph.D. dalam kimia dan fisika dari Institut Teknologi California.

Pada tahun 1956, setelah dua tahun bekerja di Laboratorium Fisika Terapan di Johns Hopkins, Moore kembali ke California, tempat dia mengambil pekerjaan sebagai ahli kimia penelitian di Shockley Semiconductor. Salah satu rekan kerjanya adalah Robert Noyce, tamatan Perguruan tinggi Grinnell dengan gelar Ph.D dalam Enginering Dari Institut Teknologi Massachusetts. Shockley Semiconductor seharusnya merupakan tempat kerja yang menarik, ini adalah kelompok penelitian dengan dana cukup yang dioperasikan oleh William Shockey, yang memenangkan hadiah Nobel pada tahun 1956 untuk perannya dalam menciptakan transistor. Dengan mengalirkan impulses melalui "semikonduktor" yang dipres di antara dua kepingan, transistor menggantikan tabung hampa udara dalam elektronik, merintis jalan untuk pembuatan radio yang lebih kecil ukurannya. Terobosan ini akhirnya akan merintis jalan menuju pembuatan komputer pribadi. Ia bergabung dengan lulusan Caltech William Shockley di divisi Shockley Semiconductor Laboratory dari Beckman Instruments, tapi kemudian meninggalkan perusahaan tersebut sebagai "delapan pengkhianat", ketika Sherman Fairchild setuju untuk mendukung mereka membentuk perusahaan Fairchild Semiconductor.

Adalah salah satu hukum yang terkenal dalam industri mikroprosesor yang menjelaskan tingkat pertumbuhan kecepatan mikroprosesor. Diperkenalkan oleh Gordon E. Moore salah satu pendiri Intel. Ia mengatakan bahwa pertumbuhan kecepatan perhitungan mikroprosesor mengikuti rumusan eksponensial.

Perkembangan teknologi dewasa ini menjadikan Hukum Moore semakin tidak Relevan untuk meramalkan kecepatan mikroprossesor. Hukum Moore, yang menyatakan bahwa kompleksitas sebuah mikroprosesor akan meningkat dua kali lipat tiap 18 bulan sekali, sekarang semakin dekat ke arah jenuh. Hal ini semakin nyata setelah Intel secara resmi memulai arsitektur prosesornya dengan code Nehalem. Prosesor ini akan mulai menerapkan teknik teknologi nano dalam pembuatan prosesor, sehingga tidak membutuhkan waktu selama 18 bulan untuk melihat peningkatan kompleksitas tapi akan lebih singkat

Akan tetapi, saat ini Hukum Moore telah dijadikan target dan tujuan yang ingin dicapai dalam pengembangan industri semikonduktor. Peneliti di industri prosesor berusaha mewujudkan Hukum Moore dalam pengembangan produknya. Industri material semikonduktor terus menyempurnakan produk material yang dibutuhkan prosesor, dan aplikasi komputer dan telekomunikasi berkembang pesat seiring dikeluarkannya prosesor yang memiliki kemampuan semakin tinggi.

Secara tidak langsung, Hukum Moore menjadi umpan balik (feedback) untuk mengendalikan laju peningkatan jumlah transistor pada keping IC. Hukum Moore telah mengendalikan semua orang untuk bersama-sama mengembangkan prosesor. Terlepas dari alasan-alasan tersebut, pemakaian transistor akan terus meningkat hingga ditemukannya 
teknologi yang lebih efektif dan efisien yang akan menggeser mekanisme kerja transistor sebagaimana yang dipakai saat ini.

Meskipun Gordon Moore bukanlah penemu transistor atau IC, gagasan yang dilontarkannya mengenai kecenderungan peningkatan pemakaian jumlah transistor pada IC telah memberikan sumbangan besar bagi kemajuan teknologi informasi. Tanpa jasa Moore mungkin kita belum bisa menikmati komputer berkecepatan $3 \mathrm{GHz}$ seperti saat ini.

Hukum Moore, diakui banyak pihak sebagai pendorong revolusi komputer. Secara singkat dapat disebutkan bahwa jumlah transistor chip komputer dengan harga yang sama meningkat dua kali lipat setiap 18 bulan. Kecenderungan tersebut terbukti benar sampai saat ini. Jika chip pertama Intel tahun 1971 hanya memuat 2300 transistor, chip terakhir mampu memuat 1,7 milyar transistor.

Hukum Moore bukan sekadar prediksi dan hasil pengamatan belaka. Saat ini, Hukum Moore telah dijadikan target dan tujuan yang ingin dicapai dalam pengembangan industri semikonduktor. Gordon Moore mulai dengan prediksi bahwa masa depan elektronika berhubungan erat dengan masa depan IC (integrated circuit) - teknologi yang belum populer saat itu. IC akan mendorong perkembangan komputer pribadi, termasuk piranti penghubung antarkomputer, pengendali otomatis untuk kendaraan, dan piranti komunikasi portabel. Moore menuliskan tahap perkembangan IC dengan menyatakan bahwa pada harga yang sama, kemampuan IC meningkat dua kali lipat setiap tahun.

Tidak bisa dipungkiri bahwa hukum Moore menggerakkan industri yang ingin selalu meningkatkan kemampuan chip-nya.Kita ambil contoh sebagai berikut. Peneliti di industri prosesor berusaha mewujudkan Hukum Moore dalam pengembangan produknya. Produsen alat produksi IC berusaha membuat alat yang dapat mencetak transistor sekecil mungkin. Industri material semikonduktor terus menyempurnakan produk material yang dibutuhkan prosesor, dan aplikasi komputer dan telekomunikasi berkembang pesat seiring dikeluarkannya prosesor yang memiliki kemampuan semakin tinggi.

Secara tidak langsung, Hukum Moore menjadi umpan balik (feedback) untuk mengendalikan laju peningkatan jumlah transistor pada keping IC. Hukum Moore telah mengendalikan semua orang untuk bersama-sama mengembangkan prosesor. Terlepas dari alasan-alasan tersebut, pemakaian transistor akan terus meningkat hingga ditemukannya teknologi yang lebih efektif dan efisien yang akan menggeser mekanisme kerja transistor sebagaimana yang dipakai saat ini.

Moore mengatakan "Kekuatan mikroprosesor menjadi dua kali lipat setiap 18 bulan.

Kekuatan komputasi menjadi dua kali lipat setiap 18 bulan.

Harga komputasi berkurang setengahnya setiap 18 bulan." Semakin berkembangnya teknologi, maka sebuah permasalahan dalam bidang pendidikan juga semakin kompleks sehingga perlu adanya sebuah formulasi di dalam menjawab tantangan tersebut. Hukum moore menunjukkan bahwa teknologi akan selalu berkembang. Semakin berkembang maka secara teoritis akan semakin canggih pula penerapannya dan semakin pula biaya yang dikeluarkan. Begitu pula dengan pembelajaran PAI, dengan media yang semakin canggih maka efektifitas dan efisiensi pengalaman pembelajaran akan semakin mudah pula.

\section{Implikasi Hukum Metcalfe dalam Perkembangan Teknologi Pendidikan}

\section{Islam}

Lahir pada 7 April tahun 1946 di Brooklyn, New York. Putra dari seorang teknisi rekayasa dan dibesarkan di Long Island, New York. Lulus dari Bay Shore High School pada tahun 1964, dan pada tahun 1969 lulus dari MIT dengan dua B.S. derajat, yakni di Tehnik Elektro dan Manajemen Industri dari Sloan School of Management MIT. Setelah itu melanjutkan sekolah pascasarjana diMassachusetts Institute of Technology, Harvard University dan mendapatkan gelar MS pada tahun 1970. Inilah "Father of Ethetnet", Robert Melancton Metcalfe seorang 
insinyur, teknologi eksekutif, kapitalis ventura, dan tentunya dia merupakan salah satu pengembang Ethernet. Definisi dari Ethernet itu sendiri adalah jenis skenario perkabelan dan pemrosesan sinyal untuk data jaringan komputer.

"Nilai atau kekuatan jaringan telekomunikasi adalah sebanding dengan kuadrat jumlah pengguna yang terhubung dari sistem (n2)" (Robert Metcalfe - penemu teknologi Ethernet LAN-pada tahun 1970) Hukum metcalfe ini memberikan banyak efek dalam jaringan telekomunikasi dan jaringan internet, jaringan sosial serta WWW (World Wide Web.). Saat ini dapat dikatakan bahwa kehidupan seseorang tidak akan lepas dari yang namanya jaringan telekomunikasi terutama jaringan (internet). Mulai dari membaca berita, mencari bahanbahan kuliah, mengunduh lagu, berkirim sms, memantau keadaan rumah melaui cctv via ponsel atau tablet, dan lain sebagainya yang mana hal-hal tersebut dapat dilakukan dengan adanya jaringan telekomunikasi atau internet.

Di sini yang memiliki peran penting adalah jaringan itu sendiri. Dengan adanya jaringan, seseorang dapat terhubung dengan yang lainnya dengan mudah. Entah itu melalui jaringan telekomunikasi misalnya melalui ponsel ataupun memalui jaringan internet seperti facebook, fasilitas email, chatting, dan lain-lain. Apa yang dikemukakan oleh Robet Metcalfe memanglah benar tentang nilai jaringan telekomunikasi yang sebanding dengan kuadrat jumlah pengguna yang terhubung ke dalam jaringan tersebut.

Kita ambil contoh pada layanan jaringan yang disediakan oleh Blackberry yang beberapa tahun ini mengalami peningkatan dalam jumlah penggunanya. Ketika Blackberry hadir pertama kali di Indonesia, orang-orang pasti bertanya apa kelebihan Blackberry dibanding dengan vendor-vendor penyedia ponsel yang menggunakan jaringan dari provider-provider lokal.

Mungkin pertama kali satu dua orang mencoba memakai produk Blackberry yang memiliki jaringan tersendiri serta memiliki fasilitas push email dan Blackberry Messenger (BBM). Dengan push e-mail semua e-mail masuk dapat diteruskan langsung ke ponsel. Pengguna tidak perlu mengakses Internet terlebih dulu dan membuka satu persatu e-mail yang masuk, atau pemeriksaan e-mail baru. Hal ini dimungkinkan karena pengguna akan terhubung secara terus-menerus dengan dunia maya melalui jaringan telepon seluler yang tersedia. Alat penyimpanan juga memungkinkan para pengguna untuk mengakses data yang sampai ketika berada di luar layanan jangkauan nirkabel. Dengan adanya kelebihan pada jaringan Blackberry maka satu persatu masyarakat mulai tertarik untuk menggunakannya dan hasilnya adalah fantastis. Ketika pertama kali dikenalkan di akhir tahun 2004, jumlah pengguna Blackberry semakin lama semakin banyak dan hal ini sesuai dengan hukum Metcalfe itu sendiri.

a. Segmentasi pasar, yaitu tindakan mengidentifikasi dan membentuk kelompok pembeli atau konsumen secara terpisah. Masing-masing konsumen ini memiliki karakteristik, kebutuhan produk, dan bauran pemasaran tersendiri. Diketahui bahwa pasar jasa pendidikan dari sudut marketing secara sederhana dapat dikelompokkan ke dalam dua segmen pasar yaitu pertama, segmen pasar emosional yaitu kumpulan pelanggan yang datang mendaftar atau bergabung ke sebuah lembaga pendidikan karena pertimbangan religiousitas, pasar ini kurang memperhatikan harga kualitas, mutu dan ketersediaan jaringan (networking) yang memadai. dan kedua, segmen pasar rasional; adalah pelanggan yang benarbenar sensitive terhadap perkembangan dan kualitas mutu pendidikan.

b. Targeting, yaitu membagi pasar menjadi kelompok pembeli yang dibedakan berdasarkan kebutuhan, karakteristik, atau tingkah laku yang mungkin membutuhkan produk yang berbeda. Secara umum segmentasi pasar dapat dipilih berdasarkan segmentasi geografis, segmentasi demografi, segmentasi manfaat, psikologi, segmentasi sosioekonomi, segmentasi pengunaan, dan segemntasi berdasarkan jasa.

c. Positioning, yaitu penetapan posisi pasar. Karakteristik dan pembedaan 
(differensiasi) produk yang nyata yang memudahkan konsumen untuk membedakan produk jasa antara satu lembaga dengan lembaga lainya. Posisioning berkaitan dengan bagaimana pemasar membedakan jasanya dengan pesaing (memilih pesaing). Tujuannya adalah untuk membangun dan mengkomunikasikan keunggulan bersaing produk yang ada di pasar ke dalam benak konsumen.

Unsur taktik pemasaran (market share tactic) meliputi:

a. Selling yang terkait dengan penjualan. Pengelola Perguruan Tinggi hendaknya dapat mengkomunikasikan pesan-pesan pemasaran Perguruan Tinggi yang diharapkan pasar. Sekolah sebagai lembaga ilmiah akan lebih elegan apabila bentuk-bentuk komunikasi disajikan dalam bentuk/format ilmiah, seperti menyelenggarakan kompetensi bidang studi, forum ilmiah/seminar dan yang paling efektif adalah publikasi prestasi oleh media independen seperti berita dalam media massa, komunikasi yang sengaja dilakukan sekolah dalam bentuk promosi atau bahkan iklan sekalipun perlu menjadi pertimbangan. Bentuk dan materi pesan agar dapat dikemas secara elegan namun menarik perhatian agar sekolah tinggi tetap dalam image sekolah Tinggi sebagai pembentuk karakter dan nilai yang baik. Publikasi yang sering dilupakan namun memiliki pengaruh yang kuat adalah promosi "mouth to mouth" (mulut ke mulut). Alumni yang sukses membagi pengalaman (testimony) atau bukti keberhasilan sekolah Tinggi. Komunikasi pemasaran pendidikan dapat mengunakan strategi komunikasi proaktif (proactive strategies).

b. Differensiasi. Differensiasi; adalah strategi yang memberikan penawaran yang berbeda dibanding penawaran yang diberikan kompetitor, strategi differensiasi mengisyaratkan perusahaan mempunyai jasa atau produk yang mempunyai kualitas ataupun fungsi yang bisa membedakan dirinya dengan pesaing. Strategi differensiasi dilakukan dengan menciptakan persepsi terhadap nilai tertentu pada konsumen. Misalnya: persepsi mengenai inovasi produk, brand image yang lebih unggul, dan lain-lain.

c. Bauran pemasaran (marketing mix). Bauran pemasaran adalah terkait dengan kegiatan mengenai produk, harga, promosi, dan tempat atau yang lebih dikenal dengan sebutan 4P, yaitu product, price, promotion, dan place dan $7 \mathrm{p}$ yaitu product (produk jasa), price (harga jasa), promotion (promosi), person (sumber daya jasa), physical evidence (bukti fisik/sarana prasarana), dan process (manajemen layanan jasa) untuk pemasaran jasa.

Unsur nilai pemasaran (heart share) meliputi brand, service, dan process;

a. $\quad$ Brand Image; Konsumen dalam membeli sesuatu sebenarnya bukan hanya sekedar membutuhkan barang tersebut, tetapi ada hal lain yang diharapkan dibalik barang tersebut. Citra (image) adalah impresi perasaan atau konsepsi yang ada pada public mengenai perusahaan, mengenai suatu obyek, orang atau mengenai lembaga. Citra terbentuk dari bagaimana lembaga melaksanakan kegiatan operasionalnya yang mempunyai landasan utama pada segi layanan. Banyak cara dapat dilakukan untuk menarik perhatian publik dalam rangka pembentukan image terhadap lembaga pendidikan baik melalui daya tarik fisik bangunan maupun daya tarik yang bersifat akademik.

b. Service dan process; pelayanan Perguruan Tinggi terlihat sebagai apa yang diharapkan konsumen. Kesenjangan yang sering terjadi adalah adanya perbedaan persepsi kualitas maupun atribut jasa pendidikan.

Metcalfe mengatakan "Nilai atau kekuatan jaringan telekomunikasi adalah sebanding dengan kuadrat jumlah pengguna yang terhubung dari sistem (n2)". Dalam pandangan ini, pada dasarnya dengan adanya jaringan yang lebih luas maka akan berimplikasi pada pengetahuan yang lebih luas dan mendalam pula. Kita dapat menemukan dan menggali informasi dan melakukan sharing dalam suatu sitem yang tertata dengan baik. Kekuatan jaringan apabila disokong bersama-sama dengan adanya sistem yang kuat akan sangat mempengaruhi penerapan dalam pembelajaran. Semakin banyak akses terhadap materi pembelajaran PAI, maka akan semakin banyak pula fitur dan konten yang disajikan terkait dengan pembelajaran PAI sebanding dengan kebutuhan bahkan lebih. 


\section{Implikasi Hukum Coase dalam Perkembangan Teknologi Pendidikan Islam}

Ronald Harry Coase merupakan seorang ahli ekonomi asal Amerika. Ia juga merupakan seorang profesor bidang ekonomi di University of London External Program pada 1927 sampai dengan 1929. Coase menempuh studi di London School of Economics di mana ia menjadi mahasiswa Arnold Plant yang juga banyak mempengaruhi pola pikir ekonomi Coase. Ia sempat dianugerahi Nobel Memorial Prize in Economics pada 1991.

Ronald Harry Coase lahir di Willesden pada 29 Desember 1910. Ayahnya merupakan seorang ahli telegram di sebuah kantor pos. Sebagai seorang anak, Coase memiliki kelemahan pada kakinya yang memaksanya untuk memakai kaki buatan dari besi. Karena kekurangannya ini, ia masuk ke sekolah yang menerima siswa dengan keterbatasan fisik. Pada usia 12 tahun ia berhasil masuk ke Kilburn Grammar School dengan beasiswa sebelum akhirnya kuliah di University of London.

Ia pertama kali bekerja di University at Buffalo dan menjadi warga negara Amerika. Pada 1958 ia pindah ke University of Virginia sebelum akhirnya menjadi editor Journal of Law and Economics. Coase memiliki dua artikel yang sangat terkenal yaitu "The Nature of the Firm" (1937) dan "The Problem of Social Cost" (1960). Artikelnya yang pertama menceritakan tentang konsep biaya transaksi untuk menjelaskan norma dan batasan sebuah perusahaan. Sementara artikel keduanya menceritakan tentang teori properti yang dapat menjamin masalah-masalah eksternal. Coase juga sering dianggap sebagai bapak reformasi di kebijakan alokasi spektrum elektromagnetik berdasarkan artikelnya "The Federal Communications Commission" (1959) di mana ia mengkritik perijinan spektrum yang menganjurkan hak properti sebagai metode alokasi spektrum kepada pengguna yang lebih efisien. Pendekatan biaya transaksi Coase kini sangat mempengaruhi organisasi ekonomi modern.

Coase mengatakan; "Bersamaan dengan biaya transaksi yang menurun, sebuah organisasi kecil pun berkembang". (Ronald Coase). Dalam dunia IT, komponen biaya kadang menjadi hal yang sangat rumit. Seharusnya dengan adanya IT, sebuah perusahaan akan terbantu dalam pekerjaan serta dalam hal menghasilkan profit dengan kemudahan-kemudahan yang ditawarkan oleh IT. Akan tetapi hal itu akan sangat berbeda jika sudah masuk ke dalam ranah perawatan, upgrade ataupun perbaikan IT yang dimiliki perusahaan. Bisa-bisa perusahaan harus mengeluarkan biaya ekstra untuk hal tersebut. Hal ini juga lah yang kadang menghambat perusahan-perusahaan skala kecil yang ingin bersaing dan tetap eksis dengan menginginkan adanya dukungan IT yang handal dikarenakan biaya untuk pengadaan dan perawatan serta perbaikan IT yang tidak bisa dibilang murah. Jika ini terus menerus terjadi, maka sangat tidak menguntungkan bagi organisasi atau perusahan kecil.

Coase mengatakan "Bersamaan dengan biaya transaksi yang menurun, sebuah organisasi kecil pun berkembang". Semakin banyak kajian dan akses terhadap materi pembelajaran PAI, maka efisiensi guru di dalam menanamkan dan membuka wawasan terhadap peserta didik akan lebih luas. Apabila dihitung dari nilai ekonomis, pembelajaran dengan mengaju pada hukum coase akan lebih ekonomis, karena pada dasarnya apabila semakin banyak produk yang dikelola dan dihasilkan maka biaya yang dikeluarkan akan semakin sedikit karena sikapnya ditanggung bersama. 


\section{Simpulan}

Pada dasarnya perkembangan hukum teknologi bersinergi dengan perkembangan teknologi dan informasi. Semakin berkembangnya teknologi, maka secara otomatis semakin tarik menariklah hukum teknologi informasi. Sebagaimana kita ketahui semakin banyak pemakai teknologi maka semakin banyak pula jaringan dan informasi yang disajikan dan semakin murah pula biaya yang dikeluarkan.

Berkaitan dengan dunia pendidikan. Dengan adanya hukum-hukum teknologi dan informasi maka berimplikasi pula pada perkembangan pendidikan agama Islam sehingga lebih efisien dan efektif sehingga pendidikan akan tepat guna. Perlu digarisbawahi meskipun demikian teknologi ibarat candu, menyebabkan ketergantungan dan sifatnya instan. Dengan kata lain, apabila pembelajaran diterapkan dengan berbasis teknologi apabila ada suatu hal yang menyebabkan kerusakan pada teknologi maka pembelajaran tidak dapat berjalan. Teknologi informasi ibarat mata uang koin, mempunyai dua mata sisi, yaitu ; sisi negatif dan sisi positif, sehingga guru di dalam menyampaikan materi tidak menjadikan teknologi informasi sebagai sumber melainkan sebagai media dalam pembelajaran.

\section{Daftar Pustaka}

Donald H. Sanders, 2000, Computers Today, McGraw-Hill Book.

Griffin, Emory A., 2003, A First Look at Communication Theory, 5th edition, New York: McGraw-Hill.

Misa, TJ, 1994. Mengambil perubahan sociotechnical dari determinisme teknologi. Dalam MR Smith \& L. Marx (Eds.), Apakah sejarah teknologi drive: Dilema determinisme teknologi. Cambridge, MA: MIT Press.

Sumarsono dkk, 2010, Teknologi Informasi dan Komunikasi Yogyakarta : FAK Tarbiyah UIN Suka

Tim Jurnalistik Ash-Shohafi, 2005, Cyber Education, Yogyakarta: Mu'allimin.

Harina Yuhetty 2008, Edukasi Net Pembelajaran Berbasis Internet : Tantangan dan Peluangnya, Jakarta : Kencana Pranada Media Group. 